\title{
A 'Rule of Thumb' and the Return on Investment: The role of valuation devices in the financialization of Northern Australian pastoral land
}

\author{
Alexandra Langford
}

\begin{abstract}
Northern Australian pastoral land prices have become higher and more volatile over the last twenty years, raising concerns about the potential implications of the financialization of the industry. These prices are not inevitable results of market forces, but mediated and co-constructed by a range of actors using two valuation devices: the 'Beast Area Value', a 'rule of thumb' which emerged during the early development of the industry, and the 'Return on Investment', a tool widely used to compare financial ventures. The Beast Area Value treats land as a commodity whose value is derived from its physical characteristics, while the Return on Investment treats land as an asset whose value is based on its future income generation potential. This article describes how some pastoral companies are strategically combining these devices to earn capital gains through 'speculative development' of properties in ways that do not necessarily increase their productivity. It argues that pastoral land is often developed in ways more reflective of the valuation devices used in the region than of the realities of station management, representing a shift from competing in the sphere of production to competing in the sphere of valuation and implicating these devices in the financialization of Northern Australian land.
\end{abstract}

Keywords: assetization, commensuration; financialization; Northern Australia; pastoral land

Alexandra (Zannie) Langford is a Research Fellow in the School of Agriculture and Food Sciences at the University of Queensland, Australia

\author{
(C) 2021 The author (cc) BY This work is licensed under a Creative Commons \\ Attribution 4.0 International License. \\ https://doi.org/10.3384/VS.2001-5992.2021.8.2.37-60 \\ Hosted by Linköping University Electronic press \\ http://valuationstudies.liu.se
}




\section{Introduction}

In Northern Australia, the increasingly high and volatile prices of pastoral land have raised concerns around the potential implications of the 'financialization' of the industry. Financialization is broadly conceived as the 'increasing importance of financial markets, financial motives, financial institutions, and financial elites in the operation of the economy and its governing institutions' (Epstein 2001: 2) such that profit making increasingly occurs through financial rather than productive activities (Krippner 2005). Agri-food scholars have raised concerns around the effects of financialization, such as a reorientation of agri-food industries to conform to the needs of financial shareholders (Williams 2000; Isakson 2014, Kuns et al. 2016; Clapp and Isakson 2018); concentration of power in supply chains (Burch and Lawrence 2013); rising farmland prices (Magnan and Sunley 2017); increasing food system governance by financial actors (Langford et al. 2020); and declining viability of family farms (Alston 2004; Weller et al. 2013). Combined with literature highlighting a global 'land rush' (Scoones et al. 2013) and food regime restructuring (McMichael 2012), these studies have raised substantial concerns about the role of financial investment in food production.

However, there is increasing recognition of the need to go beyond meta-narratives of financialization to examine its more nuanced, geographically situated and culturally embedded construction (Ouma 2015; Henry and Prince 2018: 990; Sippel 2018). Financial investment in land and agribusiness do not follow a clear and predictable path (Ducastel and Anseeuw 2017; Muniesa et al. 2017; Langford 2020) but is mediated by a range of professionals who negotiate demand and supply (Bessy and Chauvin 2013; Ducastel and Anseeuw 2017) and draw on different calculative devices (Henry 2017). Understanding the movement of finance and its outcomes requires opening the 'black box' of various processes of financial work (Ouma 2015) to investigate how multiple stakeholders come together to 'negotiate the shape, features, aims and means of capitalization work' (Muniesa et al. 2017: 55). A focus on valuation as a process contributes an understanding of how things are made valuable (Kornberger et al. 2015), both by financial entities creating investment products (Ducastel and Anseeuw 2017; Visser 2017; Langford et al. 2021a) and professional intermediaries who, 'beyond their apparent specific function (providing services of buying and selling, matching, advising and evaluating), are all engaged in activities of valuation that shape the market' (Bessy and Chauvin 2013: 84).

The value of land is an obvious but crucial driver of investment. Land is '[1]ike gold with yield' (Fairbairn 2014: 589), the yield being profits from agricultural production and the gold being the land itself. This framing captures two ways of valuing land: as a commodity with inherent value related to its qualities and as an asset whose value is 
related to the future income it returns. These divergent ways of valuing land are based on different understandings of its value. Commodities are valued in markets through a process of 'qualification' in which they are described according to a set of characteristics and ranked relative to each other (Beckert and Musselin 2013: 1). By contrast, assets are valued through a process of capitalization, or more narrowly defined, assetization: a 'form of valuation that propels a consideration of return on investment' (Muniesa et al. 2017: 11). An asset is not designed to be broken up into its component parts, but to generate sustainable and ongoing income. As Birch and Muniesa (2020: 2) observe, '[a]ssets can be bought and sold, yes. But the point is to get a durable economic rent from them, not to sell them in the market today'.

Birch and Muniesa (2020) consider the shift from commodification to assetization to be a key feature of techno-scientific capitalism, and associate this with a shift from the logic of market speculation to that of capital investment. Associated with this is a shift in 'critical analytical attention away from a focus on commodification and price speculation and towards concerns with the appropriation of value and extraction of rent through capital investment' (Langley et al. 2021: 510). However, as Braun (2020) cautions, the asset-commodity dichotomy is more fluid in practice and some goods - including land are treated as commodities and assets by different people at different times. The pragmatic approach of Muniesa (2012) offers one way to explore land value assemblages by presupposing that land has no inherent value as either a commodity or an asset, but is made valuable through varied processes of valuation undertaken by various actors at different times. Exploring how a diverse range of actors assemble the value of land through contingent and contested valuation processes reveals how land values - which drive investment in land and underpin the financial viability of cattle properties - are generated in practice.

In Northern Australia, land has typically been valued using the Beast Area Value (BAV), a 'rule of thumb' (Vail 2014: 32) for commensuration of diverse landholdings based on a simplified set of characteristics. In this valuation process, a pastoral station's value is derived from the sum of the land value, the cattle value, and the value of any infrastructure developments made to it. The land is valued as a commodity in a process of valuation-qua-marketization (see Muniesa et al. 2017: 130). However, financial investment in pastoralism in the region is seeing properties increasingly valued using the Return on Investment (ROI), a measure commonly used by investors to estimate the value of an investment based on its expected future income streams in a process of valuation-qua-capitalization (Muniesa et al. 2017: 130).

These different valuation devices often produce divergent land prices based on different understandings of value. Examining how value is constructed by different actors using competing valuation devices reveals the 'disputability and multiplicity of value 
regimes' (Arjaliès in Kjellberg et al. 2013: 19), and how the increasing presence of financial sector actors is shifting the way that value is constructed in the Northern Australian pastoral industry. It allows us to move beyond a view of financialization as simply 'a vague notion of "the (increased) contemporary importance of finance"' (Christophers 2015: 184) to examine ways in which new financial actors in agriculture interact with local people and established calculative devices to produce assets in particular ways (see Goldman 2020). This serves to 'expand the cast of actors, human and nonhuman, that participate, or are made to participate in the drawing together of generally fragile assemblages' (Henry 2017: 102). It can offer a more nuanced understanding of how negative effects often associated with financialization - such as land price volatility - are generated in practice. This can allow for more targeted policies that differentiate between different types of financial investment to improve outcomes for the industry.

This research is part of a project exploring the financialization of land and agribusiness in Australia, for which over 100 semi-structured interviews were undertaken between 2016 and 2019. This article draws on a subset of 40 of these interviews focusing specifically on financial intermediaries to land and agribusiness in Northern Australia, including land valuation professionals, investors, farmers, rural lenders and government actors. Interviews ranged in duration from 40 minutes to over three hours, with an average duration of 1 hour 13 minutes. This article begins by describing the process for valuing land using BAV, revealing how value is negotiated by farmers and valuation professionals. I then discuss how the ROI is driving assetization processes in which pastoral stations are increasingly organized as assets, and how this appears to reduce the capacity for speculation on land as a commodity by treating it as an asset from which durable economic rent should be derived. I then show how ROI and BAV are being strategically combined in ways that incentivize development activities that do not necessarily improve station profitability. Through these studies I argue that pastoral land is being assetized and developed in ways that are more reflective of the valuation devices that are influential in the region than of the realities of station management.

\section{Valuing land as a commodity using the Beast Area Value}

Beef pastoral land in Northern Australia is typically low rainfall, remote land, mostly held on long-term leases administered by the Commonwealth government. The leased land provides the government with rental payments and can be bought and sold in land markets. Properties tend to be very large and sold at costs that are low on an area basis; even relatively small properties are typically several 
thousand square kilometres in area. This apparently low-cost land, coupled with investment reports emphasizing 'market fundamentals' such as growing middle-class populations and shrinking resource bases, have bolstered expectation of future land value rises and have fuelled financial investment. Over the past 20 years, with increasing transactions in Australian beef pastoral land (Rural Bank 2017), land prices have risen considerably and become substantially more volatile (Figure 1). This effect has been concentrated on the largest, corporately owned stations, although family enterprises have also experienced appreciation as a result. This has occurred without an equivalent increase in farm income. Indeed, the financial viability of this pastoral investment is underpinned by gains on land value rises, which historically have made up more than half of return on investment (MLA 2021).

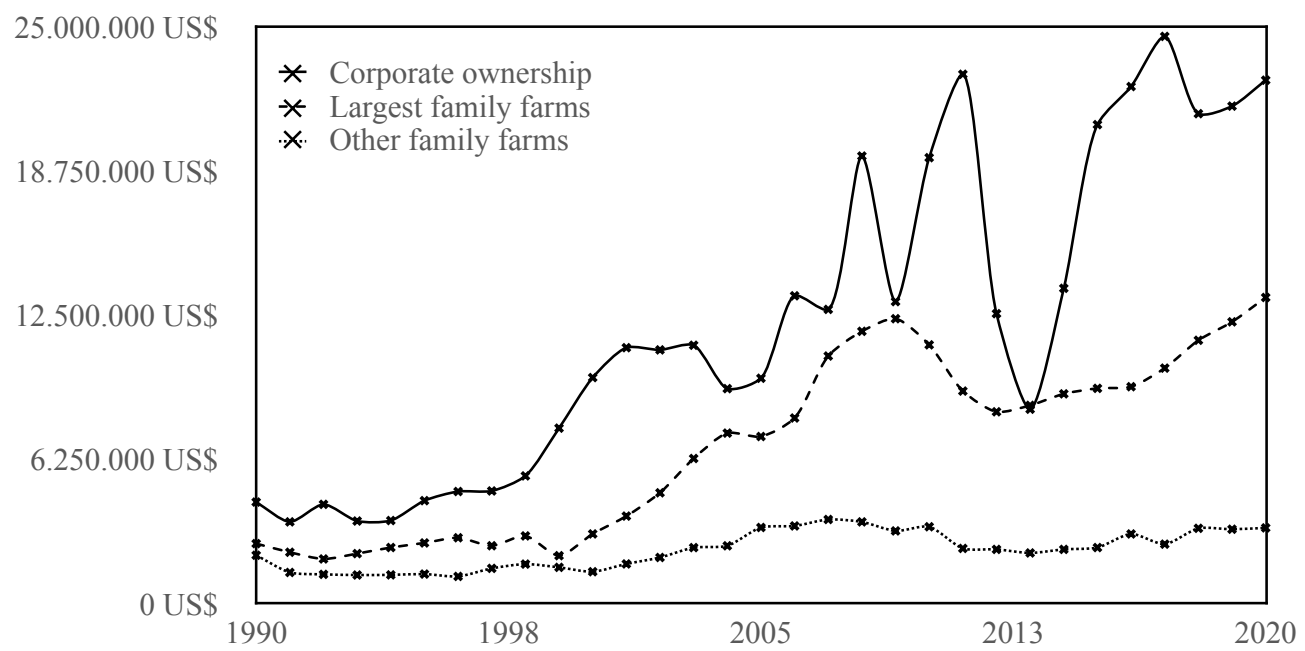

Figure 1 Land value of Australian pastoral zone beef farms by ownership type 1990-2020, showing the increasingly high and volatile land prices of corporately owned properties in particular.

Source: Data from MLA (2021), expressed in \$AU 2020-21.

Prior to 1970, pastoral properties in Northern Australia had relatively little market value, and governments historically struggled to encourage people to occupy and use the land (Hartwig 1965; Powell 2009 [1982]). Apart from a few major corporate holdings, properties were typically unfenced, with very little infrastructural development (Powell 2009 [1982]). Most properties were held on leasehold, and the land itself had very little capital value, due to the very large amount of land available and the difficulty in profiting from it. Scarcity, a key condition for assetization (Visser 2017) was not a key feature of the land market. Stations were typically sold on the basis of an estimate of 
the number of cattle that were living on them - it was the cattle, not the land, which had the most value (see Figure 2).

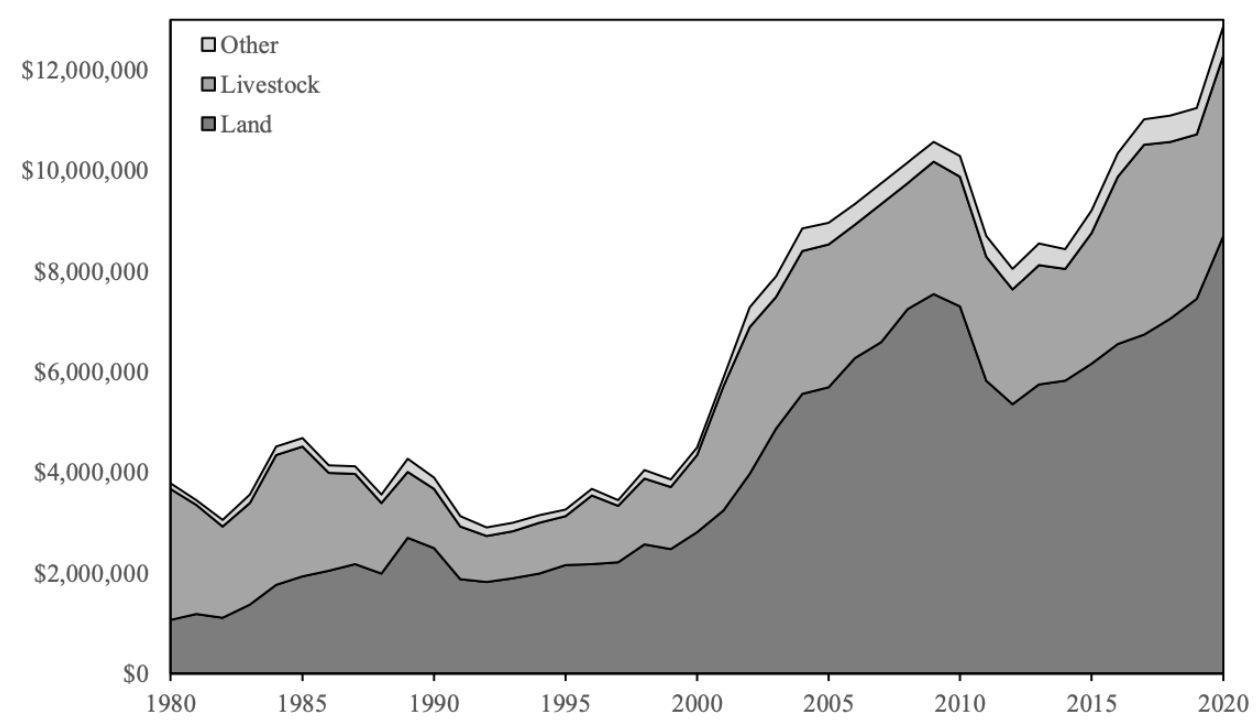

Figure 2 Capital value of beef farms in Australia's pastoral zones 1980-2020, showing a dramatic increase in the value of the land relative to that of livestock and other capitaAcknowledgment: Thanks to Giselinde Kuipers and to Frédéric Vandberghe for their helpful comments on a previous version of this article.

Source: Data from MLA 2021 (\$AU 2020-21).

During these early years of the pastoral industry, BAV emerged as a basic industry 'rule of thumb' (Vail 2014) to enable the buying and selling of different pastoral properties. These properties were very large and contained a variety of different land types with differing suitability for grazing. A simple tool was required to facilitate the description of these diverse landholdings according to a common metric, a process that Espeland and Stevens (1998) describe as 'commensuration' (1998: 315). The metric settled upon was the 'best area' or 'carrying capacity' of the property. Rather than selling a property based on its area, pastoralists would make a transaction based on the number of cattle who could live on it sustainably. This enabled buyers and sellers in markets to quickly assess the approximate size of pastoral businesses which varied greatly in size and land types.

Beckert and Musselin (2013) describe how goods are organized in markets through qualification, 'a collective process in which products become seen as possessing certain traits and occupying a specific position in relation to other products in the product space' (2013: 1, emphasis added). This two-step process aligns with the 
process for valuing pastoral land using BAV, which involves first, describing the property according to its physical characteristics and deriving from these a single figure for the number of cattle the property can support; and second, ranking the property relative to other properties, which may vary by remoteness, infrastructure developments, seasonality and other relevant factors. This process is highly complex in practice, requiring specialist skill sets held primarily by professional land valuation specialists. It is worth exploring here how these professionals undertake this valuation process.

In valuing land using BAV, land valuers first seek to describe the land according to a limited number of its physical characteristics - a process that 'flattens' (Kornberger 2017) land's diverse 'affordances' (Li 2014: 589) into a subset of features deemed valuable. These features - such as area, rainfall, vegetation type, degradation and availability of permanent water sources - are used to estimate the number of cattle that can sustainably live on the property in the long term. Assessing these qualities is not a trivial matter. Properties cover vast areas and often contain land that varies substantially by soil type, vegetation, topography, and water availability, and in many parts of Northern Australia, there is limited availability of environmental mapping data. In addition, the features of land vary substantially with weather cycles and with intensity of cattle stocking, and so vary from season to season, year to year, and between decades. They are highly vulnerable to overgrazing and invasion of unwanted vegetation species, which can substantially erode the health of the land and cause permanent damage. In addition, improvements made by pastoralists (such as water developments or supplemental feeding) can be included and subtracted from valuations in different ways. As such, the number of cattle currently living on the property rarely aligns with the longterm sustainable average number of cattle that can live on it, and it is this long-term average that forms the basis of BAV.

As such, professional pastoral valuers need a skill set that is specialized to the cattle grazing industry and to their particular region of Northern Australia. They must combine an ability to assess environmental features of many types of pastoral land, an understanding of the behaviour of grazing cattle, and an ability to assess other important features of the land that affect cattle grazing patterns. This leads to highly specialized and spatialized valuation skill sets that are not transferable across regions. As one professional valuer described,

when we value a property we have to base a lot of it on our own experience of what we know country [land] type in that certain region can do ... I certainly wouldn't go outside of my borders and pretend I could value [elsewhere] ... I understand how tricky it is to understand a region up here, and there's so many nuances of our particular region that you would not know if you just flew in for a week. 
The professional valuer estimates the sustainable carrying capacity through a combination of environmental observation, review of business records and interviews with local informants. They fly over and/or drive around a property to observe its environmental features and the interaction of cattle with the land. These observations last several days, depending on the size of the property, but due to the vast areas of properties the observations that can be made in this time are relatively limited. As a result, the pastoralist owner or manager of a property features heavily as a key informant in the valuation process, to point out important features of the land. As one professional valuer put it:

You always want to drive round it or be on the inspection with someone who knows the property pretty well, 'cos you obviously want them to point out [important features]. They might have been there for twenty years, so you want to pull in everything you can off them.

The pastoralist's role as informant is to indicate important features of the land to the professional valuer, as well as to provide information on the business management which helps valuers to interpret their observations. Some features are likely to increase valuation, such as natural water sources, while others will reduce it, such as the encroachment of an undesirable weed. These features can be difficult to notice and require long-term detailed observation of the property, which are often exclusively obtained by the pastoral station owner/ manager, creating a key role for them in the valuation process. One pastoralist described that in their experience, professionally determined carrying capacities were not "instructed", but “negotiated" ... to a mutual agreement' (Armstrong and Armstrong 2017: 2). Indeed, one government commissioned valuation was overturned because the professional valuer had been 'insufficiently influenced by the estimates of the well-experienced owners' (Keough \& Wirth v Department of Natural Resources and Mines 2004: 15), who had advised the professional valuer on the limitations of the property. Pastoralists thus feature as central informants in a valuation process while simultaneously being directly affected by its outcome. This is reminiscent of a capitalization story described by Muniesa et al. (2017: 71), who noted that 'figures are neither blindly accepted nor completely disregarded, but are discussed, corrected and revised throughout the discussions between entrepreneurs and potential investors'. This occurs primarily between valuation professionals and pastoralists, but others are also involved at times. One rural agrifinance specialist described their role in property valuations in the following terms: '[W]e do property inspections, so we will drive around looking at a property ... I take photos so that someone external to me can put a value on the property'. Valuation specialists emphasize their role in interpreting reports from various sources 'to 
make sure that the property is correctly described' (emphasis added) that is, as objectively assessed as possible given the constraints on information.

Once the valuer has assigned the property a carrying capacity effectively a descriptive measure of its size - the property is ranked relative to other properties for which sale prices are available. This 'requires decisions to be made about which properties are superior to others and vice versa. They effectively need to be "ranked" in order from best to worst' (Peacocke 2017: 2). As the influential professional valuer Frank Peacocke ${ }^{1}$ put it, 'it is the valuer's skills, I guess, to look at that one and say, "It is definitely two-thirds better than that one, or $90 \%$ as good as that one" (EPSC 2018a: 17). Assigning BAV in this way requires robust data on recent sales and detailed knowledge of the local market - as one professional valuer explained, each valuer is 'just constantly monitoring the market in [their] area of expertise'. This ranking requires accounting for 'qualitative factors' (Peacocke 2017: 2) such as location, development potential and market risks. Frank Peacocke described the difficulty in obtaining these skills, stating that 'it has taken me 10 years just to get my head around the relativities. That is how long it takes' (EPSC 2018a: 17).

These rankings are compared against recent sale data to estimate the value of a property. However, this task is not as simple as using market price directly, since price fluctuations in the region are often extreme and vary with weather and financial cycles. Rather, valuers attempt to differentiate between sale price and what they describe as the 'true value' Brewarrana Pty Ltd $v$ Commissioner of Highways (No. 1) (1973: 197-80) of a property. They are tasked not with assessing what purchasers are paying, but with predicting what they refer to as a 'rational purchaser' would pay for any given parcel of land. Valuations are therefore not reflective of current land markets, but of what 'rational' buyers in a hypothetical future land market could be expected to pay. As Wells J described in Brewarrana Pty Ltd $v$ Commissioner of Highways (No. 1) (1973: 197-180, emphasis added), 'the sale price of any given piece of land is not necessarily the price at which it ought to have been sold, or the same thing as its true value'. In a context where land sales substantially above market prices are

1 Frank Peacocke is the director of valuation firm Herron Todd White in the Northern Territory, and the valuer chosen to undertake valuations for all Northern Territory properties for the government's 2015 assessments. 
relatively common, ${ }^{2}$ these sales must be excluded since they do not represent predictable behaviour of this hypothetical rational purchaser.

Professional valuers therefore do not use all past sales equally as evidence of market activity but assess the quality of the sale in deciding how much weight to give it in predicting future behaviour. One professional valuer highlighted the need to 'keep bringing it back to the hard evidence, culling out the bad evidence', and lamented sales that they believed to be excessively above market prices, noting that

when [the valuer] analyses the sale, [they] need ... to find out who bought it, why, and how much due diligence they did, and also who else was in the running for the property, and how far behind were they, and how much do they know. If you get one where the agent will say 'These folks really did their due diligence', then you say that's good evidence from a well-informed purchaser in this market, so that's good evidence (emphasis added).

Valuers assess whether buyers carried out their due diligence by comparing the price paid with an estimate of the value of the land as calculated using ROI - treating the land as an asset. This is a contemporary development which has altered the process for valuing land using BAV and suggests that they consider the 'true value' of the land to be that produced by valuing the land as an asset, and by extension, that the true form of the land is that of an asset. This reflects the market for professional land valuations, which are used by non-specialist investors to guide their purchasing decisions, by banks as an assessment of the value of pastoralists' assets in making decisions about how much finance to extend, and by governments as the basis of lease rates payable. These actors value the land not as a home or as something with inherent environmental, cultural or social value, but as an asset with a definable financial value.

This reveals that BAV valuations are assembled by a host of geographically situated human and non-human actors, from pastoralists and land valuation professionals to government lease policies and bank lending ratios. The resulting land market reflects the work of these diverse actors undertaking valuation processes, and the interactions between them. Although this historical device nominally treats land as a commodity, it is increasingly influenced by a view of land as an asset that should return a stream of future income which

\footnotetext{
2 One response to the high and volatile property prices has arisen in the Northern Territory, which is moving away from a market-based system of valuation to determine lease payments, in a highly controversial move which will assign property values using not market rankings, but a general 'regional index'. The amendment was justified by the government on the grounds that "its benefits, such as its simplicity and lack of volatility, outweigh its imperfections" (EPSC 2018b: 19). Although it reduces the impact of market volatility on prices, it does not conceptually change the process of valuing land using the BAV.
} 
affects the advice that valuation professionals offer in their reports. The next section explores the process for valuing land using the ROI.

\section{Valuing land as an asset using the Return on Investment}

ROI is calculated as the sum of returns from farm income and returns from capital gains, as shown below (adapted from Beattie 2021).

$$
\begin{gathered}
\mathrm{ROI}=\mathrm{ROI}_{\text {income }}+\mathrm{ROI}_{\text {capital gains }} \\
\text { where } \\
\mathrm{ROI}_{\text {income }}=\text { Total profit over life of investment } / \text { Property purchase price } \\
\mathrm{ROI}_{\text {capital gains }}=(\text { Property sale price }- \text { Property purchase price }) / \text { Property purchase price }
\end{gathered}
$$

The projected ROI can be difficult to estimate due to the large size of properties, their remoteness and a lack of information on farm performance, seasonal conditions and commodity prices, which make it difficult to assess future income. As valuer Tim Lane $(2017$, n. p.) notes, these features make it 'quite challenging to apply capitalization rate for investors and give them indicators that are utilized commonly in the corporate investment world'. This means that ROI from farm income and ROI from capital appreciation are calculated using existing data, making station records an increasingly important component of farm value, and driving corporatization processes in which family farm businesses increasingly need to mirror investment reporting standards (see Langford 2019 for an account of this process).

ROI from capital gains is based on the increasing land prices in the region (Figure $3 \mathrm{~b}$ ) which are higher and more volatile than those from farm income (Figure 3a). There are substantial differences between properties with corporate ownership and between the larger and smaller family farmers. While since the year 2000 all properties have appreciated at an average rate of $3.8-3.9 \%$ per annum, corporate properties have earned an average ROI from farm incomes of $3.3 \%$, the largest family farmers of $2.6 \%$, and the remaining family farmers of $-0.3 \%$ (see Figures $3 \mathrm{a}$ and $3 \mathrm{~b}$ ). The smaller family farmers typically make a loss if their enterprises are assessed as an asset, which interviewees suggested to be a result of factors such as their operation of properties for non-financial reasons and management of properties in ways designed to reduce tax liabilities rather than increase profit. It also implies that these properties are overvalued relative to returns generated from them, suggesting that for these farmers, ROI does not capture the value of the property. In the Gulf country of Queensland, Martin (2019: 131) contrasts the family operator's 'commitment to the land' with 'an understanding of property as fungible, and essentially interchangeable with any other financial asset'. He quotes one long- 
term Gulf resident describing the station on which he grew up as 'the deepest root' (Martin 2019: 134) and emphasizes their connection to the land and the region. From this perspective, the 'true value' of a property lies in its materiality, and a diverse range of affordances not captured by ROI.

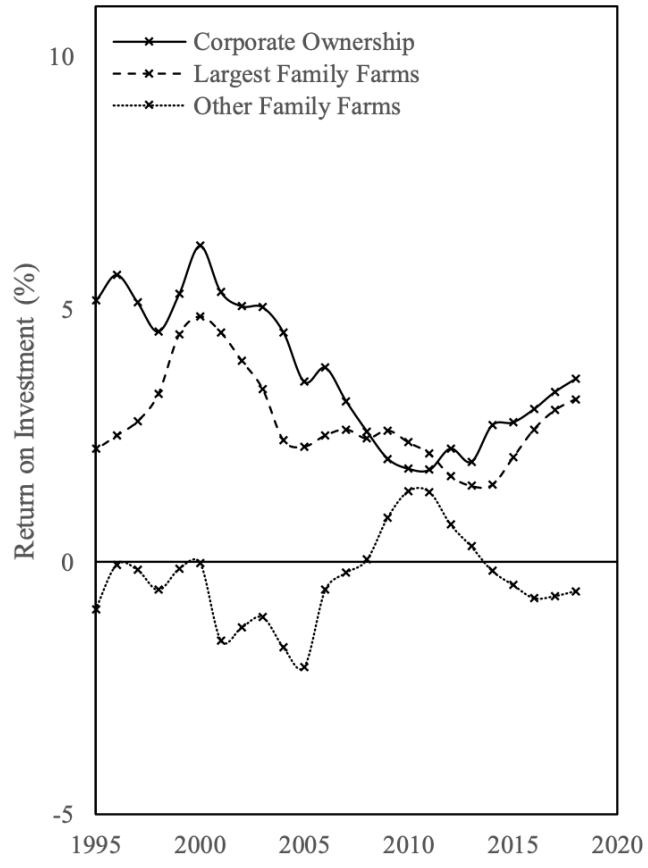

(3a)

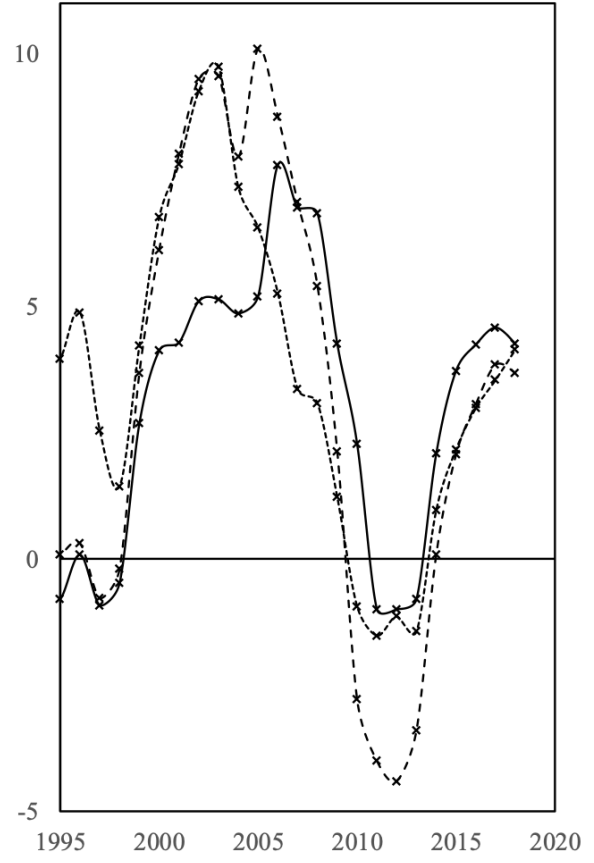

(3b)

Figure 3 Rate of return from Australian pastoral zone beef farms (5year simple moving average) from (a) farm income and (b) capital appreciation, showing low and stable returns from income and fluctuating returns from capital gains.

Source: Data from MLA (2021).

Despite this, the practice of assessing property value using ROI-based measures is becoming more widespread with the increasing influence of actors who view land as a financial asset. Pastoralists often need access to finance, and sources of both debt and equity finance increasingly requires stations to be organized in a way that makes ROI calculable. While pastoralists are often accustomed to viewing station value as derived from the characteristics of the land, livestock and development (as a commodity), investors and bankers view the property as a stream of future income (as an asset), and encourage farmers to develop reporting systems that enable ROI-based valuations. Although this seems obvious, many family-owned 
properties in remote Northern Australia either do not keep, or do not wish to disclose, records of their business income, and as a result, bankers in the region maintain very close relationships with their clients in order to assess their asset value and ability to service debt (see Langford et al. 2021b). In this context, bankers exert pressure on farmers to develop certain reporting systems in order to access finance - a process of valuation driven by a view of the land as an asset. One banker described the tension between these different views of station value - his own need to know the financial details of the property, and a pastoralist's assertion that the value of the property can be assessed by consideration of its physical features and cattle stocking rate:

In the Northern Territory we sell a cattle station as a walk-in walk-out business, but if I'm selling it to you, I'm not going to show you my books. You name me another business that can be sold on a walk-in walk-out basis without the books. Without three- or five-years' financial records. What they say to you is, 'I've got twenty thousand head of cattle, this is my herd breakup, I've got so many cows; work out what you think it's worth. You do the math'. If, as an investor, you are looking to invest in these businesses, you're not going to invest in something like that. You want to know what the EBITDA $^{3}$ is. No different to me as a banker as with financing. I need to know what your earnings before interest and tax and depreciation are, so I can work out what you can service. But that is the traditional method of selling stations

An alternative approach to accessing finance is to seek an equity investor in the pastoral business, a popular but somewhat elusive alternative to bank finance. Pastoralists who reorganize their business reporting systems in order to attract investors are engaged in an act of valuation in the sense that they both demonstrate the value of the business by recording those features needed to calculate ROI, and create value for investors by making it possible to measure the business value, monitor it from afar and organize its place in a portfolio (for a case study exploring the experience of a cattle farmer undertaking a capitalization process, see Langford 2019, and for a discussion of these two understandings of valuation processes, see Vatin 2013). This shows how valuation devices influence the activities of pastoral station managers as they develop reporting systems that are compatible with ROI (for a related discussion see Ducastel and Anseeuw 2017). The needs of the investor that farmers respond to - such as the need for a system recording business management in a way that enables an investor to calculate investment returns - are devices which shape the assetization of the business.

This section has described ROI-based valuations which develop assessments of station value based on farm income. However, ROI also includes consideration of the future sale price of the property, in which

${ }^{3}$ Earnings Before Interest, Tax, Depreciation, and Amortization (EBITDA) 
the BAV - as the valuation device used by professional land valuers features, as the next section discusses.

\section{Speculative development and the strategic combination of valuation devices}

In choosing how to develop stations, the calculative device used to value stations matters. Developments undertaken targeting farm income-based measures must weigh up the cost of building and maintaining infrastructure against the increased income they expect to gain from it - developments must 'pay for themselves' over a certain lifespan through the increased income they generate. Conversely, developments targeting increased capital gains on an imminent sale do not need to justify themselves against increases in income if they can capture an increase in property value greater than the cost of development.

This creates space for a strategic combination of ROI and BAV to realize higher returns on investment. As Kornberger (2017) notes, valuation devices influence not only what we buy, on the consumption side, but also what is sold, on the production side, since businesses can change what they produce to better fit valuation devices. In this sense, there is a shift from competing in productive spheres to competing in valuation spheres, in which different actors may exert strategic agency to improve the way their product performs according to different valuation devices. In Northern Australia, producers develop pastoral stations through use of fencing and watering points to increase utilization of the station's vegetation, and by extension the number of cattle they can support. This approach increases the carrying capacity of the property, leading to a direct increase in the property price as measured by BAV. This increase in station value is often greater than the cost of development, as one corporate pastoral company described:

One thing that we would look at if we were to buy a property is what sort of future potential does it hold in terms of value of that property. We would look at how much utilisation it currently has and how much scope there is to develop additional land there, and by that I mean by putting on more watering points, which then allows you to run more cattle on that property, and by putting those additional water points, when the properties get independently valued each year, those valuers look at the land on a carrying capacity basis, so how much in an average season can this property hold in terms of cattle numbers. So that means any development that we do is increasing the value of that property, and what we're finding is that we can develop the property at a cheaper rate per hectare than what that hectare can end up being worth, so we make that margin, if you like, on the development activities.

This productive investment in station development is directly targeting the BAV valuation device in order to realize higher ROI from capital 
gains. Unlike property development undertaken targeting farm incomes, which must weigh up the cost of building and maintaining infrastructure against the increased income they expect to gain from it, developments targeting BAV in anticipation of capital gains on an imminent sale do not need to justify themselves productively, but only against increases in property value as calculated using BAV. Thus investors may be able to earn substantial capital gains through property development that targets carrying capacity, even if the costs of maintaining additional cattle and infrastructure on marginal lands lead farm profits to remain the same or even decrease. ${ }^{4}$ Development could paradoxically reduce farm incomes while increasing farm values. Because business records are not publicly disclosed, it is not possible to tell whether recent pastoral development investment is justified by an increase in returns, and there is the potential for this speculative approach to development to compromise the sustainability of the industry.

Similarly, it remains to be seen how professional valuers - who are responsible for verifying these increases in value - will respond to such development, given the contested nature of BAV as a measure of value. One professional valuer described such a case in which they had refused to value the property at the BAV-informed higher rate without being provided with business records (to enable an assessment of the value using ROI), saying that 'it's up to the person that developed it to prove that it works'. In this case, the valuer and the property developer expressed conflicting understandings of land value informed by differing moral reasoning: the developer located their morality in their development expenditure (for related discussions see Kish and Fairbairn 2018; Sippel 2018; Ouma 2020) and the valuer in their concern for the stability of the industry. In a context where volatile land prices have had severe negative impact on many pastoralists in the region due to some unsustainable bank financing practices ${ }^{5}$ and the changing lease payments 6 they cause, some valuation specialists see a role for their advice in reducing overpayments for properties and therefore in moderating land markets. As one professional valuer stated:

\footnotetext{
4 Cattle health is a major driver of station profitability, as it is not the number of cattle itself that drives farm income, but the number of calves they produce (for breeding properties). Unsustainable stocking rates can therefore actually decrease the number of calves that are produced if food is not sufficient for cattle to reach conception weight.

${ }^{5}$ Including overextending debt due to both incompetence (Weller and Argent 2018) and intentional manipulation of land valuations (e.g. Ludlow 2018, Neales 2018).

${ }^{6}$ For example increases of up to $441 \%$ in the Northern Territory in 2009 (EPSC 2018a).
} 
as valuers, you want to make sure that fires are [contained]. In the end that makes our job easier, you go 'That's a well-informed purchaser. That's a good sale. The market's not getting out of whack' (emphasis added).

This sentiment positions the valuer as not merely reflecting the market, but regulating it, by preventing above-market sales from escalating into unsustainable land value increases. These negotiations highlight the ways that various actors exploit and contest valuation processes in pursuit of different outcomes.

\section{Discussion: Assembling value}

The valuation practices described here shape the way in which pastoral land is organized, used and traded in Northern Australia. BAV treats land as a commodity in a process of valuation-qua-marketization (see Muniesa et al. 2017: 130) in which the pastoral property is described and ranked according to its physical characteristics. The station's value is not totally disconnected from its earning power, as the feature by which it is defined - the carrying capacity - is a rough measure of its earning potential. However, it is an indirect and approximate indication of earning potential, where the station is valued as the sum of its parts (such as the land, buildings, cattle and fencing), rather than as a stream of future income. The increasing use of ROI, by contrast, represents a process of valuation-qua-capitalization in which the pastoral station is viewed as a stream of future revenue. ROI translates the diverse array of land's characteristics 'into something that makes sense in terms if future cash flows' (Muniesa et al. 2017: 21), a process that sees the nature and temporality of a business's value redefined according to the expectations of investors.

What are the implications of treating land as a commodity or asset in this way? First, treating land as a commodity increases its availability to speculation, and BAV is widely viewed as contributing to high and volatile land prices in the region as a result of the potential disconnect between the BAV price and the income of the property. Purchasing a property without station records requires buyers to have in-depth specialist knowledge of station management to interpret BAV land valuations and estimate the profitability of the investment. Professional land valuers provide some assistance to purchasers by supplementing their valuations with in-depth comments around the basis of the valuation and cautions for its use. Yet it remains that station prices can often diverge substantially from their long-term profitability as a result of financial and weather cycles, and this introduces volatility into land markets which can be challenging for producers in the region. Even pastoralists who are not interested in buying or selling properties are affected by shifting land prices through changes to their lease payments, the financing they are offered by banks, and cattle prices. 
Contrarily, valuing land as an asset by standardizing value against the income it generates is viewed favourably by local government actors and industry professionals in the region as it is seen to reduce this speculative behaviour through a focus on business financial sustainability - as Muniesa et al (2017: 51) write, assetization is 'what you do in order to protect something from the vagaries of commodification'. Bankers and investors seeking equity partnerships drive processes in which pastoral properties are assetized to provide clear reporting on key features of interest to investors seeking to calculate ROI. This often involves increased data collection and improved management of station financial records. This is not a new process and is not driven exclusively by financial investors, but often by farmers as they seek to access finance (see Langford 2019). In addition, professional land valuers are increasingly producing land valuations which while nominally based on BAV calculations, draw in some part on ROI to inform their interpretation of the price data on which BAV valuations are based.

However, assets are also subject to speculation, and as Kornberger (2017) notes, it is possible to compete outside the sphere of production, in the sphere of valuation, by designing goods and assets in ways that target valuation devices rather than seeking to maximize profitability. This is occurring in Northern Australia where pastoral companies - typically those backed by large institutional investors with the capacity to expend substantial funds on trading and developing properties - are undertaking station development programmes designed to increase the station's 'best area', and therefore its value. This is profitable for investors, who make a capital gain on such developments regardless of whether they increase or decrease station profitability. For example, adding infrastructure such as fences and watering points to remote parts of a property would increase the number of cattle that could live on the property, and therefore its BAV valuation - regardless of whether the costs of maintaining these improvements and mustering the cattle from a remote area outweigh the increased income. This type of speculative development 'reflects the assessment of future earnings that accrue to the owner, rather than rising productivity' (Birch and Muniesa 2020: 7).

These divergent, overlapping and competing approaches to valuation are implicated in the financialization of the industry in unexpected ways. If financialization is considered to be increased profit-making from financial rather than productive channels (Krippner 2005), the financialization of the Northern Australian cattle industry could be located in the speculative trading of properties for capital gains rather than their long-term productive operation. This process is facilitated and resisted by actors using BAV and ROI valuation processes in different ways. Professional valuers increasingly use ROI to connect station value to its productive uses to reduce the 
potential for speculation; yet pastoral companies simultaneously combine ROI and BAV in an attempt to generate capital gains through speculative development. This suggests that although the industry appears to suffer from financialization as evident in its high and volatile land prices, it is not simply the entrance of financial investors who drive this process, but their engagement with local actors and calculative devices across unique and varied geographies.

\section{Conclusion}

The financialization of Northern Australian pastoral land has been associated with high and volatile land prices in the region, which have been attributed to speculative behaviour by non-specialist investors. However, closer attention to the processes of valuation through which these land prices are made reveals that a range of local and non-local, human and non-human actors contribute to the assemblage of these values through diverse, sometimes competing and sometimes complementary, work. Valuation professionals use BAV to construct valuations of land based on their physical characteristics, yet supplement these assessments with detailed comments warning that the 'true value' of the land is better estimated using ROI. Pastoralists develop reporting systems to enable bankers, investors and professional valuers to measure their station value using ROI, while simultaneously asserting non-financial connections to the land. Investors buy properties based on ROI-based calculations, and then seek to sell them using BAV-based valuations, strategically using these competing valuation processes selectively to profit from speculative development activities. This reveals that valuation devices play a key role in the financialization of Northern Australian land, but not in a clearly reducible way: rather, land values are assembled by the interactions of a diverse range of actors undertaking unique valuation processes in pursuit of individual goals.

\section{Acknowledgements}

I would like to thank the people who generously participated in this research, whose wealth of experience informed this article. The research was enabled by funding from the Australian Government Research Training Program Scholarship, the Australian Research Council Discovery Project (160101318), and the University of Queensland School of Social Science Fieldwork Grant.

\section{References}

Alston, Margaret. 2004. "Who is down on the farm? Social aspects of Australian agriculture in the 21st century." Agriculture and Human Values 21(2): 37-46. 
Armstrong, John, and Helen Armstrong. 2017. "Submission No. 1 - John and Helen Armstrong”, Economic Policy Scrutiny Committee, Pastoral Land Legislation Amendment Act, Gilnockie Station, Northern Territory, Australia. https://parliament.nt.gov.au/ data/assets/pdf file/ 0004/464251/Submission-No.-1-John-and-Helen-Armstrong.pdf.

Beattie, Andrew. 2021. "A Guide to Calculating Return on Investment (ROI)." Investopedia. Available at https://www.investopedia.com/articles/ basics/10/guide-to-calculating-roi.asp, accessed 14 September 2021.

Beckert, Jens, and Christine Musselin. 2013. “Introduction”. In Constructing Quality: The Classification of Goods in Markets, edited by J. Beckert and C. Musselin, 1-30. Oxford: Oxford University Press.

Bessy, Christian, and Pierre-Marie Chauvin. 2013. "The Power of Market Intermediaries: From information to valuation processes." Valuation Studies 1(1): 83-117.

Birch, Kean, and Fabian Muniesa (2020). "Introduction: Assetization and Technoscientific Capitalism”. In Assetization: Turning Things into Assets in Technoscientific Capitalism, edited by K. Birch and F. Muniesa, 1-41. Cambridge, MA: MIT Press.

Braun, Veit. 2020. "From Commodity to Asset and Back Again: Property in the Capitalism of Varieties". In Assetization: Turning Things into Assets in Technoscientific Capitalism, edited by K. Birch and F. Muniesa, 203224. Cambridge, MA: MIT Press.

Brewarrana Pty Ltd $v$ Commissioner of Highways (No. 1) (1973) 32 LGRA 170 at $179-180$.

Burch, David, and Geoffrey Lawrence. 2013. "Financialisation in Agri-Food Supply Chains: Private Equity and the Transformation of the Retail Sector." Agriculture and Human Values 30(2): 247-258.

Christophers, Brett. 2015. "The Limits to Financialisation." Dialogues in Human Geography 5(2): 183-200.

Clapp, Jennifer, and S. Ryan Isakson. 2018. "Risky Returns: The Implications of Financialization in the Food System". Development and Change 49(2): 437-460.

Ducastel, Antoine, and Ward Anseeuw. 2017. "Agriculture as an Asset Class: Reshaping the South African Farming Sector." Agriculture and Human Values 34(1): 199-209.

EPSC (Economic Policy Scrutiny Committee). 2018a. "13th Assembly of the Economic Policy Scrutiny Committee, Public Hearing Transcript". Legislative Assembly of the Northern Territory. https:// parliament.nt.gov.au/_data/assets/pdf_file/0008/485630/FINALTRANSCRIPT-ECONOMIC-POLICY-SCRUTINY-COMMITTEEFriday-2-February-2018.PDF, accessed 15 December 2018.

EPSC (Economic Policy Scrutiny Committee). 2018b. "Inquiry into the Pastoral Land Legislation Amendment Bill 2017”. Legislative Assembly of the Northern Territory. https://parliament.nt.gov.au/_data/assets/pdf_file/ 0009/488925/Inquiry-into-the-Pastoral-Land-Legislation-AmendmentBill-2017.pdf, accessed 15 December 2018. 
Epstein, Gerald. 2001. Financialization, Rentier Interests, and Central Bank Policy.. Amherst, MA: University of Massachusetts, Department of Economics, December.

Espeland, Wendy N., and Mitchell L. Stevens. 1998. "Commensuration as a Social Process." Annual Review of Sociology 24: 313-343.

Fairbairn, Madeleine. 2014. "'Like Gold with Yield': Evolving Intersections between Farmland and Finance." The Journal of Peasant Studies 41(5): 777-795.

Goldman, Michael. 2020. "Dispossession by Financialization: The End(S) of Rurality in the Making of a Speculative Land Market". Journal of Peasant Studies 47(6): 1251-1277.

Hartwig, M.C. 1965. "The Progress of White Settlement in the Alice Springs District and its Effect upon the Aboriginal Inhabitants, 1860-1894.” PhD thesis. University of Adelaide, South Australia.

Henry, Matthew. (2017). "Meat, Metrics and Market Devices: Commensuration Infrastructures and the Assemblage of 'the Schedule' in New Zealand's Red Meat Sector.” Journal of Rural Studies 52: 100-109.

Henry, Matthew, and Russell Prince. 2018. "Agriculturalizing Finance? Data Assemblages and Derivatives Markets in Small-Town New Zealand." Environment and Planning A: Economy and Space 50(5): 989-1007.

Isakson, S. Ryan. 2014. "Food and Finance: The Financial Transformation of Agro-Food Supply Chains." The Journal of Peasant Studies 41(5): 749775 .

Keough \& Wirth $v$ Department of Natural Resources and Mines (2004). QLC 101.

Kish, Zenia, and Madeleine Fairbairn. (2018). "Investing for Profit, Investing for Impact: Moral Performances in Agricultural Investment Projects." Environment and Planning A, 50(3): 567-588.

Kjellberg, Hans, Alexandre Mallard, Diane-Laure Arjaliès, Patrik Aspers, Stefan Beljean, Alexandra Bidet, Alberto Corsín, Emmanuel Didier, Marion Fourcade, Susi Geiger, Klaus Hoeyer, Michèle Lamont, Donald MacKenzie, Bill Maurer, Jan Mouritsen, Ebba Sjögren, Kjell Tryggestad, François Vatin, and Steve Woolgar. 2013. "Valuation Studies? Our Collective Two Cents." Valuation Studies 1(1): 11-30.

Kornberger, Martin. 2017. "The Values of Strategy: Valuation Practices, Rivalry and Strategic Agency." Organization Studies 38(2): 1753-1773.

Kornberger, Martin, Lise Justesen, Anders Madsen, and Jan Mouritsen (eds.) 2015. Making Things Valuable. Oxford: Oxford University Press.

Krippner, Greta. 2005. "The Financialization of the American Economy." Socio-Economic Review 3(3): 173-208.

Kuns, Brian, Oane Visser, and Anders Wästfelt. 2016. "The Stock Market and the Steppe: The Challenges Faced by Stock-Market Financed, Nordic Farming Ventures in Russia and Ukraine." Journal of Rural Studies 45: 190-217.

Lane, Tim. 2017. "The Valuation of Agricultural Assets in Australia." Grains Research and Development Corporation. https://grdc.com.au/resources- 
and-publications/grdc-update-papers/tab-content/grdc-update-papers/ 2017/06/the-valuation-of-agricultural-assets-in-australia

Langford, Alexandra. 2019. "Capitalising the Farm Family Entrepreneur: Negotiating Private Equity Partnerships in Australia." Australian Geographer 50(4): 473-491.

Langford, Alexandra. 2020. Agri-Food Transformations in Northern Australia: The Work of Local Actors in Mediating Financial Investments. $\mathrm{PhD}$ Thesis, School of Social Science, University of Queensland, South Australia. https://doi.org/10.14264/uql.2020.698.

Langford, Alexandra, Kiah Smith, and Geoffrey Lawrence. 2020. "Financialising Governance? State Actor Engagement with Private Finance for Rural Development in the Northern Territory of Australia". Research in Globalization 2(10026): 1-9.

Langford, Alexandra, Geoffrey Lawrence, and Kiah Smith. 2021a. "Financialisation for Development? Asset-Making on Indigenous Land in Remote Northern Australia." Development and Change 52(3): 574-597.

Langford, Alexandra, Alana Brekelmans, and Geoffrey Lawrence. 2021b. "II want to sleep at night as well': Guilt and Care in the Making of Agricultural Credit Markets." In Markets in Their Place, edited by R. Prince, M. Henry, A. Gallagher, C. Morris, and S. FitzHerbert, 122-140. Abingdon: Routledge.

Langley, Paul, Gavin Bridge, Harriet Bulkeley, and Bregje van Veelen. 2021. "Decarbonizing Capital: Investment, Divestment and the Qualification of Carbon Assets." Economy and Society 50(3):494-516.

Li, Tania M. 2014. "What is Land? Assembling a Resource for Global Investment." Transactions of the Institute of British Geographers 39(4): 589-602.

Ludlow, Mark. 2018. “Banking Royal Commission: Bankwest's Inflated Valuations Toppled Qld Farmer.” Financial Review 28 June. https:// www.afr.com/news/politics/banking-royal-commission-bankwestsinflated-valuations-toppled-qld-farmer-20180628-h11yr0, accessed 15 December 2018.

McMichael, Phillip. 2012. "The Land Grab and the Corporate Food Regime Restructuring." The Journal of Peasant Studies 39(3-4): 681-701.

Magnan, Andre, and Sean Sunley. 2017. "Farmland Investment and Financialisation in Saskatchewan 2003-2014: An Empirical Analysis of Farmland Transactions." Journal of Rural Studies 49: 92-103.

Martin, Richard. 2019. The Gulf Country: The Story of People and Place in Outback Queensland. Crows Nest, NSW: Allen \& Unwin.

MLA (Meat and Livestock Australia). 2021. "Farm Survey Data for the Beef, Slaughter Lambs and Sheep Industries." http://apps.daff.gov.au/mla/, accessed 13 September 2021.

Muniesa, Fabian. 2012. "A Flank Movement in the Understanding of Valuation.” The Sociological Review 59(2): 24-38.

Muniesa, Fabian, Liliana Doganova, Horacio Ortiz, Álvaro Pina-Stranger, Florence Paterson, Alaric Bourgoin, Véra Ehrenstein, Pierre-André Juven, 
David Pontille, Başak Saraç-Lesavre and Guillaume Yon. 2017. Capitalisation: A Cultural Guide. Paris: Presses des Mines.

Neales, Sue. 2018. "Royal Commission: Rural 'Specialist' Bank Sent Farmers to Brink". The Australian 27 June. https://www.theaustralian.com.au/ business/banking-royal-commission/rural-specialist-bank-sent-farmers-tobrink/news-story/35b136355896be0591a9729d074b633d, accessed 15 December 2018.

Ouma, Stefan. 2015. Assembling Export Markets: The Making and Unmaking of Global Food Connections in West Africa. Hoboken, NJ: John Wiley \& Sons.

Ouma, Stefan. 2020. "This Can('T) Be an Asset Class: The World of Money Management, "Society" and the Contested Morality of Farmland Investments. Environment and Planning A: Economy and Space 52(1): 66-87.

Peakcocke, Frank. 2017. "Submission No. 12A - Herron Todd White (Northern Territory) Pty Ltd". Submission to the Pastoral Land Legislation Amendment Bill. https://parliament.nt.gov.au/ data/assets/ pdf file/0009/462717/Submission-No.-12A-Herron-Todd-WhiteNorthern-Territory-Pty-Ltd.pdf, accessed 27 December 2018.

Powell, Alan. 2009 [1982]. Far Country: A Short History of the Northern Territory, 5th edn. Darwin, ANT: Charles Darwin University Press.

Rural Bank. 2017. "Australian Farmland Values 2017." https:// www.ruralbank.com.au/assets/responsive/pdf/publications/afv-2017.pdf, accessed 15 October 2018.

Scoones, Ian, Ruth Hall, Saturnino Borras, Ben White, and Wendy Wolford. 2013. "The Politics of Evidence: Methodologies for Understanding the Global Land Rush.” The Journal of Peasant Studies 40(3): 469-483.

Sippel, Sarah R. 2018. "Financialising Farming as a Moral Imperative? Renegotiating the Legitimacy of Land Investments in Australia." Environment and Planning A 50(3): 549-568.

Vail, Michael. 2014. "What is the 'True', Going Concern Value of a Pastoral Zone, Grazing Enterprise Investment in Australia: and, Why Beast Area Valuation (BAV) is Wrong?" Masters Research Project. Central Queensland University, Rockhampton, QLD.

Vatin, François. 2013. "Valuation as Evaluating and Valorizing." Valuation Studies 1(1): 51-81.

Visser, Oane. 2017. "Running Out of Farmland? Investment Discourses, Unstable Land Values and the Sluggishness of Asset Making." Agriculture and Human Values 34(1): 185-198.

Weller, Sally, and Argent, Neil. 2018. "Royal Commission Shows Bank Lenders Don't 'Get' Farming, and Rural Economies Pay the Price." The Conversation 2 July. https://theconversation.com/royal-commissionshows-bank-lenders-dont-get-farming-and-rural-economies-pay-theprice-99086, accessed 15 December 2018. 
Weller, Sally, Erin F. Smith, and Bill Pritchard. 2013. "Family or Enterprise? What Shapes the Business Structures of Australian Farming?" Australian Geographer 44(2): 129-142.

Williams, K. 2000. "From Shareholder Value to Present-Day Capitalism." Economy and Society 29(1): 1-12.

Alexandra (Zannie) Langford is a Research Fellow in the School of Agriculture and Food Sciences at the University of Queensland, Australia. Her research explores rural livelihoods and development financing in Australia, Indonesia and the Pacific. 
